\title{
IBADAH PERJANJIAN BARU SUATU URAIAN DESKRIPTIF TENTANG IBADAH DAN KONTRIBUSINYA BAGI IBADAH MASA KINI
}

\author{
FERDINAN S. MANAFE
}

\section{PENDAHULUAN}

Ibadah adalah bagian penting dari hidup keagamaan seseorang. Tidak pernah terjadi dalam dua dekade yang lalu, dimana ibadah menjadi hangat dibicarakan dalam kekristenan seperti saat ini. Tidak pernah sebelumnya ibadah menjadi sesuatu yang begitu rumit, sementara itu banyak orang keluar dari satu Gereja kepada Gereja yang lain untuk mencari dan mengalami ibadah yang benar, yang telah dimodifikasi untuk menjawab persoalan manusia, demikian pendapat Fischer, seorang penyanyi dan pengarang lagu serta penulis buku Fearless Faith. ${ }^{1}$ Selanjutnya dikatakan: statistik menunjukkan bahwa Gereja-gereja besar bertumbuh bukan karena pertobatan tetapi bentuk ibadah yang lebih baik dan populer bagaikan pipa penyedot yang menarik pengunjung ke dalam Gereja yang tadinya kecil, kemudian menjadi besar. Bahkan pemberitaan Firman Tuhan yang tadinya begitu penting, sekarang menjadi hanya sebagai tambahan kepada pujian dan penyembahan. ${ }^{2}$ Menurut Fischer: Many people go to church today more to experience God than they go to hear about Him, and they feel that they experience God mostly in the music. ${ }^{3}$ Hal ini menunjukkan adanya kehausan yang dalam dari umat Tuhan untuk bertemu dengan Allah-nya dalam ibadah.

Pemahaman tentang pengertian ibadah dalam Perjanjian Baru (PB) harus dimulai dengan memperhatikan kata-kata tertentu yang biasa digunakan dalam ibadah PB. Menurut Reimer, kata ibadah (atau ibadat) adalah istilah untuk menyebut suatu perbuatan yang menyatakan bakti kepada Allah, yang didasari oleh ketaatan mengerjakan perintah-Nya. ${ }^{4}$ Kata leiturgia berasal dari kata kerja leiturgeo, artinya melayani, melaksanakan

1 John Fischer, What to Do about The Worship Wars, Moody Magazine, July/August 2002, 18.

${ }^{2}$ Ibid.

${ }^{3}$ Ibid.

${ }^{4}$ G. Riemer, Cermin Injil (Jakarta: Yayasan Komunikasi Bina Kasih, 1995), 9. 
dinas atau tugas, memegang jabatan. ${ }^{5}$ Secara harafiah kata leiturgia berasal dari dua kata Yunani, yaitu leitos yang berarti rakyat, umat; dan kata ergon yang berarti pekerjaan, perbuatan, tugas. Jadi leiturgia berarti melakukan suatu pekerjaan untuk rakyat. ${ }^{6}$ Menurut Abineno yang dikutip Reimer, ibadah yang biasanya digunakan dalam PB bahasa Indonesia, adalah terjemahan tiga istilah Yunani, sebagai berikut: leiturgi (Kis 13:2)... beribadah kepada Allah; latreia (Rm 12:1)... mempersembahkan seluruh tubuh: threskeia (Yak 1)... pelayanan kepada orang yang dalam kesusahan. ${ }^{7}$ Dengan demikian, seluruh istilah ini adalah menunjuk kepada aktifitas manusia. Dengan kata lain, pengertian ibadah PB menunjuk kepada aktifitas ibadah manusia sebagai respons terhadap karya keselamatan Kristus, yang adalah penggenapan ibadah Perjanjian Lama. Tulisan ini bertujuan memaparkan apa itu ibadah dalam PB dan bagaimana umat Tuhan beribadah serta kontribusinya bagi ibadah masa kini.

\section{DASAR IBADAH}

Dasar ibadah PB adalah pada perjanjian Allah yang digenapi di dalam pengurbanan Kristus di kayu salib. Kristus adalah kurban yang sempurna. Kristus adalah penggenapan ibadah PL. Searah dengan pernyataan di atas, Lumintang menuliskan sebagai berikut:

Kristus menggenapi tabernakel dan Bait Allah dengan jalan Pribadi

Kedua Allah Tritunggal menjadi manusia dan tinggal di antara kita (manusia). Kehadiran Allah menjadi nyata di dalam Pribadi Yesus. Yesus adalah Allah yang tinggal di antara kita. Karena itu, ibadah kepada Allah hanya terjadi di dalam dan melalui Tuhan Yesus. ${ }^{8}$

Peterson juga menuliskan bahwa: the New Testament begins with the assurance that all history has been moving towards Jesus Christ as its goal and that he is the final and definitive manifestation of God's presence with his people, ${ }^{9}$ maka dasar ibadah Perjanjian Baru ada pada inkarnasi Yesus Kristus, sebagai penggenapan nubuatan mesianik Perjanjian Lama.

\footnotetext{
${ }^{5}$ Riemer, Cermin ..., 9.

${ }^{6}$ Ibid., 10.

${ }^{7}$ Ibid., 62

${ }^{8}$ Lumintang, Theologia Ibadah..., 36.

${ }^{9}$ David Peterson, Engaging with God (England: Apollos, 1992), 81.
} 
Dasar ibadah PB dapat ditemukan melalui mencermati sikap Yesus terhadap ibadah dan makna karya Kristus. Sikap Yesus terhadap ibadah, pertama; Yesus mendukung ibadah PL. ${ }^{10}$ Hubungan Yesus dengan Bait Allah, synagoge, dan hari raya Yahudi membuktikan kesimpulan di atas. Dalam Injil dicatat bahwa Yesus berada Bait Allah (Luk 2:21-25; Yoh 7:14-49; 10:22,23). Tetapi tidak dicatat bahwa Yesus mempersembahkan kurban binatang atau menyetujui system kurban. Menurut Lukas, Yesus secara regular mengunjungi synagoge pada hari Sabat (Luk 4:16). Yesus juga menghadiri perayaan hari raya Israel (Yoh 7:2; 10:22). Detail dari Yesus merayakan paskah sebelum perjamuan akhir membuktikan pengetahuan dan penghargaan Yesus terhadap hari raya besar Israel (Mat 26:1-30; Mrk 14:1-26; Luk 22:1-23; Yoh 13:1-30). ${ }^{11}$

Kedua, Yesus memandang institusi ibadah dalam PL menunjuk kepada diri-Nya. ${ }^{12}$ Contoh; pembersihan Bait Allah harus dilakukan bersama dengan pandangan tentang berakhirnya tempat untuk pengurbanan. Jadi makna sesungguhnya dari tindakan Yesus adalah untuk menyatakan bahwa ritual tradisional kurban adalah tidak cukup atau tidak mungkin. Dengan menghentikan system pengurbanan binatang, Yesus menunjuk diriNya sebagai penggenapan kurban yang sempurna. ${ }^{13}$ Dengan kata lain, Yesus adalah anak domba yang sempurna, dan adalah kurban yang sempurna.

Ketiga, Yesus berhak menginterpretasi tradisi ibadah Yahudi. ${ }^{14}$ Contoh; konfrontasi Yesus dan orang Farisi tentang hari Sabat. "Lalu kata Yesus kepada mereka: Hari Sabat diadakan untuk manusia dan bukan manusia untuk hari Sabat, jadi Anak Manusia adalah juga Tuhan atas hari Sabat" (Mrk 2:27,28). Tentang konfrontasi ini, Webber menyatakan: Jesus willingness to break the rulers of Sabbath carried over into His attitude toward the regulations that governed cleannes and uncleanness (Mrk 7:123), as well as the ruler regarding fasting dan prayer (Mat 6:5-8, 16-18). ${ }^{15}$ Inti dari pembicaraan Yesus dengan orang Farisi di atas adalah proclaiming Himself-His lordship, His place in the kingdom, His place in the revelation of God in history. ${ }^{16}$ Dalam hal ini, Yesus mempersiapkan jalan perubahan

\footnotetext{
${ }^{10}$ Peterson, Engaging with..., 34.

${ }^{11}$ Robert E. Webber, Worship Old \& New (Grand Rapids: Zondervan, 1982), 34.

${ }^{12}$ Ibid.

${ }^{13}$ Ibid., 34.

${ }^{14}$ Ibid., 35.

${ }^{15}$ Webber, Ibid., 34

${ }^{16}$ Ibid., 34.
} 
yang signifikan dalam ibadah bagi umat yang baru sebagai pengenapan PL di dalam diri-Nya.

Di dalam ibadah PL, berisi perayaan peristiwa di Sinai, sedangkan ibadah PB adalah proklamasi kisah Keluaran yang kedua, masuknya Kristus ke dalam dunia untuk menebus umat-Nya dari ikatan dosa. ${ }^{17}$ Kelahiran Kristus adalah wujud dari sejumlah penggenapan nubuatan dalam Perjanjian Lama. Kematian dan kebangkitan Yesus menghasilkan satu respons ibadah yang menekankan penghancuran kuasa dosa dan maut. Tema ini adalah fokus khotbah mula-mula dan pada perjamuan Tuhan. Pencurahan Roh Kudus bermanifestasi di dalam hidup manusia baru oleh karya Roh di dalam nama Yesus dan untuk menyembah-Nya.

Dengan demikian, isi ibadah PB adalah proklamasi dan respons terhadap karya keselamatan yang dikerjakan Kristus melalui kematian dan kebangkitan, serta oleh karya Roh Kudus di dalam hidup orang percaya.

\section{ELEMEN-ELEMEN IBADAH}

Mengerti elemen-elemen ibadah dalam Perjanjian Baru tidak dapat dipisahkan dari peristiwa Pentakosta dalam Kisah Para Rasul 2, dimana Gereja lahir dan dibangun, pertama-tama melalui khotbah Petrus yang mengakibatkan kurang lebih 3000 orang menerima firman dan memberi diri dibaptis (Kis 2:14-47).

Pentakosta adalah moment bersejarah berdirinya Gereja. Setelah kematian, kebangkitan, dan kenaikkan Kristus ke Sorga, maka tahapan baru sejarah kekristenan dimulai. Gereja dibangun dan didirikan oleh Roh Kudus melalui khotbah Petrus, dimana tiga ribu orang bertobat dan menyerahkan diri dibaptis (Kis 2:1-40).

Orang-orang yang telah menerima firman yang dikhotbahkan Petrus memberi diri dibaptis (Kis 2:41). Mereka bertekun dalam pengajaran para Rasul dan dalam persekutuan. Mereka selalu berkumpul untuk memecahkan roti dan berdoa (Kis 2:42). Inilah situasi ibadah Gereja pertama. Webber mengomentari teks ini dengan menyatakan: some scholar have argued for a twofold sequence of Word and sacrament. ${ }^{18}$ Hal ini menyatakan bahwa ibadah pada Gereja mula-mula berakar pada pengajaran firman Tuhan dan sakramen.

\footnotetext{
${ }^{17}$ Webber, Worship Old \&..., 34.

${ }^{18}$ Ibid., 50.
} 
Yesus Kristus adalah kegenapan ibadah PL. Maka setelah pelayanan Yesus di dunia ini, pelayanan-Nya dilanjutkan oleh para murid, dan kemudian oleh Gereja sebagai tubuh Kristus. Itulah sebabnya isi ibadah pada Gereja mula-mula adalah merupakan respons orang percaya terhadap karya Kristus, yang datang ke dalam dunia untuk membebaskan dan menyelamatkan manusia dari ikatan kuasa dosa. Berdasarkan penelitian tentang ibadah di dalam seluruh PB, Segler menuliskan sepuluh elemen ibadah sebagai berikut:

(1)Musik memiliki tempat sentral di dalam ekspresi pujian Kristen. Mereka menyanyikan mazmur dan puji-pujian serta lagu-lagu rohani dari hati mereka kepada Tuhan (Ef 5:18-20; Kol 3:16; 1Kor 14:15); (2) Pembacaan Kitab Suci adalah element penting dalam ibadah Kristen mula-mula. Yesus berdiri di Synagoge, membaca kitab suci (Kol 4:16; 1Tes 5:27; 1Tim 4:13) dan surat-surat Paulus ditulis untuk dibacakan dalam Gereja-gereja. Tidak diragukan lagi bahwa pembacaan kitab suci menjadi bagian dari perintah umum dalam ibadah; (3) Doa yang telah terbukti kuasanya pada ibadah Kristen mula-mula. Kisah Para Rasul 2:42, ${ }^{19}$ menceriterakan bagaimana keadaan jemaat mula-mula. Doa ucapan syukur, permintaan, syafaat; (4) Jemaat berkata "Amin." Amin adalah kata yang biasa digunakan jemaat dalam ibadah untuk mengekspresikan persetujuan kepada apa yang dikatakan oleh pemimpin (1Kor 14:16); 5) Khotbah atau Eksposisi kitab Suci adalah bagian dari ibadah Kristen mula-mula. (6) Nasehat adalah esensi ibadah. Penulis kitab Ibrani merasa nasehat penting bagi orang Kristen untuk "saling mendorong dalam kasih dan dalam pekerjaan baik" (Ibr 10:24); (7) Orang Kristen memberi persembahan dalam ibadah umum (1Kor 16:2; 2 Kor 9:6-7, 10-13; 2Kor 8:2-8); (8) Ibadah Perjanjian Baru dipenuhi dengan doxology atau puji-pujian (Ef 1:3); (9) Pengakuan yang terbuka telah menjadi hal praktis dalam ibadah Kristen mula-mula. Ada pengakuan dosa di depan umum dan di hadapan saksi-saksi (1Tim 6:12; Rm 10:9; Yak 5:16); (10) Ibadah Kristen juga meliputi sakramen baptisan dan perjamuan kudus. Yesus memerintahkan umat-Nya untuk membaptis dan mengadakan perjamuan kudus. ${ }^{20}$

\footnotetext{
${ }^{19}$ Kisah Para Rasul 2:42; Mereka bertekun dalam pengajaran rasul-rasul dan dalam persekutuan. Dan mereka selalu berkumpul untuk memecahkan roti dan berdoa. Ayat ini menyatakan situasi ibadah jemaat mula-mula, khususnya dalam hal doa mereka.

${ }^{20}$ Franklin M. Segler, Christian Worship (Nashville, Tennessee: Broadman \& Holman Pub., 1996), 25-27.
} 
Basden dalam The Worship Maze, tentang elemen ibadah dalam Perjanjian Baru menuliskan bahwa: The first disciples worshiped by means of prayer (Acts 2:42), singing (Col 3:16), Scripture reading, preaching and teaching (1Tim 4:13), making offerings (1Cor 16:2), and celebrating the Lord's Supper (1Cor 11:17-34). ${ }^{21}$ Dengan demikian, elemen penting dalam ibadah PB seperti dipaparkan Basden adalah lima elemen; Doa, Nyanyian, Khotbah, Persembahan dan Perjamuan Kudus.

\section{TUJUAN IBADAH}

Tujuan ibadah PB adalah memuliakan Allah Bapa yang menyatakan diri di dalam dan melalui Tuhan Yesus Kristus anak domba Allah, yang adalah kurban yang sempurna, tetapi juga yang adalah imam agung dari perjanjian yang baru. Yesus Kristus adalah sentral dalam ibadah PB. Tidak ada hal lain yang memotivasi orang Kristen mula-mula ketika mereka berkumpul dan beribadah, hanya nama Yesus. ${ }^{22}$ Hal ini nampak dalam pengucapan nama Yesus dalam doa, nyanyian yang meninggikan dan memuliakan karya Kristus, dan dalam khotbah serta pengajaran.

\section{IBADAH DALAM KITAB WAHYU}

Prinsip-prinsip teologis yang mendasar tentang ibadah telah dinyatakan di dalam kitab Wahyu sebagai kitab terakhir dari Alkitab. Untuk itu perlu dicermati bagaimana ibadah di dalam kitab Wahyu.

Wahyu kepada Yohanes adalah kitab penting tentang ibadah dalam Perjanjian Baru. Disusun dalam bentuk drama yang agung tentang kemenangan Kristus, hal ini dimulai dengan surat-surat yang dialamatkan kepada tujuh jemaat di tujuh kota di Asia Kecil dan diakhiri dengan penglihatan tentang Yerusalem baru dimana Allah tinggal di tengah umatNya (21:3), dalam menggenapi formulasi ringkas para nabi Israel tentang perjanjian, "Aku akan menjadi Allah mereka dan mereka akan menjadi umat-Ku" (Yer 31:33). ${ }^{23}$ Tentang ibadah dalam kitab Wahyu, Peterson menuliskan bahwa, 1999), 23

${ }^{21}$ Paul Basden, The Worship Maze (Downers Grove, Illinois: InterVarsity Press,

${ }^{22}$ Ibid.

${ }^{23}$ Robert E. Webber (Ed.), The Biblical Foundations of Christian Worship (Peabody, Massachusetts: Hendrickson Publishers, 1993), 21. 
A major theme of this book is the distinction between true worship and idolatry. John devides humanity into two categories, the worshippers of the dragon and the beast and the worshippers of God and the Lamb. The contrast between the two groups of worshippers reaches its climax in two visions at the end of the book. ${ }^{24}$

Untuk memahami penjelasan lebih lanjut, penulis akan memaparkan dasar teologi ibadah.

\section{$\underline{\text { Allah }}$}

Allah adalah sumber segala wahyu, wahyu Kristus juga adalah apa yang dikaruniakan Allah (1:1). Sedangkan Firman (logos) adalah milik Allah, maka disebut Firman Allah (1:2,9). Firman Allah sudah ada sejak semula, maka Firman itu adalah Allah (bnd. Yoh 1:1,2).

Allah adalah yang dahulu ada, sekarang ada, dan yang akan datang (1:4). Di dalam kurun waktu, Ia adalah yang pernah ada, sekarang ada; dalam konteks lintas waktu, Ia adalah yang akan ada selama-lamanya. Oleh karena sifat, kehendak, kuasa, hikmat, kekuatan, otoritas-Nya selamalamanya sama, maka Allah itu kekal adanya.

Allah adalah pencipta segala sesuatu $(3: 14 ; 4: 11)$. Segala sesuatu diciptakan berdasarkan kehendak Allah (4:11). Allah menciptakan langit dan segala yang ada di langit; bumi dan segala yang ada di dalamnya, laut dan segala yang ada di dalamnya (10:6). Dia yang menciptakan langit dan bumi, laut dan segala sumber air itu patut menyembah-Nya (14:7).

Allah duduk di takhta $(1: 4 ; 4: 3-11 ; 5: 1-14 ; 7: 9-17 ; 8: 3 ; 12: 5 ; 14: 3$; $16: 17 ; 19: 4,11,12 ; 21: 3,5 ; 22: 1,3)$. Hal ini menyatakan pengontrolan, kuasa serta wibawa-Nya. Di sekeliling takhta ada 4 makluk hidup, 24 tuatua, serta orang percaya yang tak terbilang banyaknya, juga disertai dengan perhiasan yang indah. Semua ini bersifat rohani dan non material. TakhtaNya sudah ada sejak semula dan berada untuk selama-lamanya. Dalam rencana Allah yang kekal, Ia ingin agar orang percaya umat tebusan-Nya menjadi warga kerajaan-Nya dan imamat-Nya (1:6; 20:6). Untuk menjadi warga kerajaan-Nya harus mengalami tebusan darah Kristus (1:5). Allah adalah Mahakuasa (1:8; 11:17) menunjukkan kuasa dan kekuatan kesempurnaan-Nya. Allah Mahatahu, tidak ada sesuatupun di luar pengetahuan-Nya; "Aku tahu perbuatanmu" (3:1).

Allah adalah hakim. Ia melaksanakan penghakiman pada waktunya (14:7). Ia adil (16:5,7); Ia mengadili seturut dengan perilaku manusia (20:12,13). Menurut Wongso,

\footnotetext{
${ }^{24}$ Peterson, Engaging with..., 264.
} 
Jika ditinjau dari seluruh kitab Wahyu, maka pasal 2 dan 3 adalah penghakiman atas para pemimpin jemaat; enam malapetaka dalam pasal 6, enam sangkakala dalam pasal $8,9,11$; tujuh malapetaka dalam pasal 15,16 ditujukan kepada orang non-percaya di sepanjang abad, serta penghakiman atas para penganiaya jemaat; Wahyu 17:18 adalah penghakiman atas Babel, pezinah, penyembah berhala serta usaha dagang ilegal dan ekonomi memegang peranan paling penting; penghakiman atas Setan (20:1-3,7,10); penghakiman ata segenap umat manusia di dunia (20:11-15). ${ }^{25}$

Itulah sebabnya otoritas Allah nampak dengan jelas dalam ungkapan, "Segera aku dikuasai oleh Roh dan lihatlah, sebuah takhta terdiri di sorga, dan di takhta itu duduk Seorang Dan keempat makhluk itu masing-masing bersayap enam, sekelilingnya dan di sebelah dalamnya penuh dengan mata, dan dengan tidak berhenti-hentinya mereka berseru siang dan malam: "Kudus, kudus, kuduslah Tuhan Allah, Yang Mahakuasa, yang sudah ada dan yang ada dan yang akan datang" $(4: 2,8)$. Menurut Scheunemann, istilah takhta menyatakan: Allah memerintah. ${ }^{26}$ Mounce menulis bahwa: The first thing that John sees in heaven is a throne. This symbol occurs more than forty times in Revelation. It symbolizes the absolute sovereignty of God. ${ }^{27}$ Istilah Takhta Allah sering digunakan dalam literatur Yahudi, seperti; "Dalam tahun matinya raja Uzia aku melihat Tuhan duduk di atas takhta yang tinggi dan menjulang, dan ujung jubahNya memenuhi Bait Suci" (Yes 6:1) dan di dalam Mazmur 47:8; "Allah memerintah sebagai raja atas bangsa-bangsa, Allah bersemayam di atas takhta-Nya yang kudus." Dengan demikian Allah dalam konteks kitab Wahyu adalah pusat ibadah. Dengan kata lain, dasar Ibadah dalam kitab Wahyu adalah pada Allah yang duduk di takhta. Dia yang duduk di takhta adalah Dia yang mencipta dunia dan segala isinya. Dia yang menyatakan diri-Nya kepada manusia, baik melalui Firman yang menjadi manusia, maupun Firman yang tertulis. Dia yang menebus manusia dari ikatan kuasa dosa. Hanya kepada Dia, segala puji, hormat dan kuasa serta kemuliaan, dari sekarang sampai selama-lamanya.

${ }^{25}$ Peter Wongso, Eksposisi Doktrin Alkitab Kitab Wahyu (Malang: Seminari Alkitab Asia Tenggara, 1996), 117.

${ }^{26}$ D. Scheunemann, Berita Kitab Wahyu (Batu: Yayasan Persekutuan Pekabaran Injil Indonesia, 1994), 70.

27 Robert H. Mounce, The New International Commentary On The New Testament; The Book of Revelation (Grand Rapids, Michigan: Eerdmands, 1977), 134. 


\section{$\underline{\text { Yesus Kristus }}$}

Selain Allah yang duduk di atas takhta, dalam kitab Wahyu Anak Domba yang menunjuk kepada Kristus juga adalah pusat ibadah. Mengapa? Mounce menjelaskan bahwa: The Lamb of Revelation is the 'Lord of lords, and the King of kings' who wages a victorious warfare against the beast and his confederates (17:12-14) and before whose wrath the men of earth call upon the rocks and mountains to fall on them (6:15-17). ${ }^{28}$

Anak Domba disembah karena Dia adalah Tuhan atas segala tuhan dan Raja atas segala raja. Searah dengan pernyataan di atas, Scheunemann menuliskan bahwa,

Di tengah-tengah penglihatan Yohanes tentang takhta Allah muncullah sebagai puncak penglihatan Anak Domba Allah antara takhta Allah dan empat zat hidup dan duapuluh empat tua-tua (5:6). Namun sekarang Anak Domba Allah mempunyai wujud yang baru. Kata yang dipakai Yohanes, ialah "anak domba kecil yang ditandai luka kematian" (Yun. arnion). ${ }^{29}$

Dengan demikian yang dimaksudkan dengan Anak Domba Allah adalah Yesus Kristus. Istilah Anak Domba Allah dipakai untuk menunjuk kepada penggenapan perjanjian ${ }^{30}$ yang Allah telah berikan kepada Adam dan Hawa setelah mereka jatuh ke dalam dosa. Dan kemudian diberikan kepada Abraham ${ }^{31}$ serta keturunannya. Jadi dasar teologi ibadah dalam kitab Wahyu adalah penggenapan perjanjian Allah kepada manusia di dalam diri Tuhan Yesus Kristus.

${ }^{28}$ Mounce, The New International Commentary..., 145.

${ }^{29}$ Scheunemann, Berita Kitab..., 73.

30 Kejadian 3:15: Aku akan mengadakan permusuhan antara engkau dan perempuan ini, antara keturunanmu dan keturunannya; keturunannya akan meremukkan kepalamu, dan engkau akan meremukkan tumitnya."

31 Kejadian 12:1-3: Berfirmanlah TUHAN kepada Abram: "Pergilah dari negerimu dan dari sanak saudaramu dan dari rumah bapamu ini ke negeri yang akan Kutunjukkan kepadamu; Aku akan membuat engkau menjadi bangsa yang besar, dan memberkati engkau serta membuat namamu masyhur; dan engkau akan menjadi berkat. Aku akan memberkati orang-orang yang memberkati engkau, dan mengutuk orang-orang yang mengutuk engkau, dan olehmu semua kaum di muka bumi akan mendapat berkat." 


\section{Roh Kudus}

Karya Roh Kudus dalam konteks kitab Wahyu lebih banyak menyatakan penggenapan dari janji Tuhan Yesus tentang penolong yang lain, ${ }^{32}$ yang akan datang dan yang menginsyafkan manusia.

Tujuh Roh dalam kitab Wahyu dipakai sebanyak empat kali (1:4; $3: 1 ; 4: 5 ; 5: 6){ }^{33}$ Roh Kudus disebut tujuh Roh, untuk menyatakan kesetaraan Roh Kudus dengan Kristus dan Allah Bapa. Dalam kitab Wahyu, empat kali mencatat Yohanes digerakkan Roh Kudus (1:10; 4:2; 17:3; 22:6). Dan empat kali gerakkan Roh Kudus membuat Yohanes mendengar, melihat fakta rohani. ${ }^{34} \mathrm{Hal}$ ini berarti tanpa Roh Kudus Yohanes tidak dapat melihat dan mengalami penglihatan yang dahsyat itu. Dengan kata lain Roh Kudus adalah dinamisator ibadah dalam kitab Wahyu.

Penulis menyimpulkan bahwa dasar teologi ibadah dalam kitab Wahyu adalah ibadah Trinitarian. Allah Bapa dengan takhta-Nya adalah center ibadah kitab Wahyu. Yesus Kristus adalah kegenapan ibadah Perjanjian Lama. Roh Kudus adalah dinamisator ibadah dalam kitab Wahyu. Lumintang menuliskan bahwa "Ibadah Kristen adalah ibadah kepada Allah Bapa di dalam dan melalui Tuhan Yesus oleh Roh Kudus." "35

\section{KARAKTERISTIK IBADAH KITAB WAHYU}

Adapun karakteristik ibadah dalam kitab Wahyu, antara lain: trinitarian, theocentric, redeemptif, theistik, covenental, dan transformatif.

\section{Trinitarian}

Kitab Wahyu dimulai dengan salam dari Tiga Pribadi dalam Trinitas $(1: 5 b, 6) ;$ “... Bagi Dia, yang mengasihi kita dan yang telah melepaskan kita dari dosa kita oleh darah-Nya, dan yang telah membuat kita menjadi suatu kerajaan, menjadi imam-imam bagi Allah, Bapa-Nya, bagi Dialah kemuliaan dan kuasa sampai selama-lamanya. Amin.

32 Yohanes 14:16 Aku akan minta kepada Bapa, dan Ia akan memberikan kepadamu seorang Penolong yang lain, supaya Ia menyertai kamu selama-lamanya,

${ }^{33}$ Wongso, Eksposisi Doktrin Alkitab..., 131.

${ }^{34}$ Ibid., 131.

${ }^{35}$ Lumintang, Theologia Ibadah..., 29. 
Doxology (1:4-8) ini berkembang secara signifikan sebagai formula dasar yang dapat ditemukan dalam surat-surat kiriman. Karya penebusan Kristus adalah penting dalam doxology. Perhatikanlah bahwa sekalipun Tiga Pribadi dari Trinitas disebut, dalam doxology ini diarahkan langsung secara jelas kepada Kristus. Dalam posisi-Nya sebagai raja, dan oleh kebajikan dalam karya penebusan yang sempurna, Kristus membuat umatNya menjadi imamat yang rajani (bnd. 1Ptr 2:9). Umat Tuhan yang berkumpul di Gereja dan di Sorga (7:9-15) adalah penggenapan dari perjanjian yang dibuat untuk Israel di Sinai; "Kamu akan menjadi bagi-Ku kerajaan imam dan bangsa yang kudus. Inilah semuanya firman yang harus kaukatakan kepada orang Israel" (Kel 19:6; bnd. 1Ptr 2:9). Konteks menyatakan bahwa doxology ini lebih merefleksikan PL dan secara sederhana mengindikasikan penggenapan perjanjian Sinai. Kemudian diikuti dengan doxology pengumuman bahwa Kristus datang di awanawan. Hal ini menyatakan satu kiasan yang kuat kepada seorang seperti anak manusia dalam Daniel 7:13.

Dalam pasal 4:1-5:14, doxology diarahkan kepada seorang yang duduk di atas takhta dan anak domba $(4: 9,11 ; 5: 12,13)$. Ini adalah salah satu dari sekian banyak liturgi yang kaya dari seluruh kitab. Memuat tidak lebih dari lima lagu pujian yang dikumandangkan keluar dari lingkaran takhta itu. Dengan kata lain, kalau dicermati, pasal 4-5 memberi alasan mengapa Allah (Bapa) dan Kristus (Anak) layak disembah: Allah menciptakan segala sesuatu (4:11) dan Kristus melalui kematian-Nya menebus manusia bagi Allah (5:9). Atau dapat dikatakan bahwa umat Tuhan menyembah Allah yang telah menciptakan langit dan bumi, dan anak domba yang telah menebus mereka di pihak yang lain, maka penyembahan menjadi powerful. Ungkapan "Pada hari Tuhan aku dikuasai oleh Roh" (1:10) menunjuk kepada karya Roh Kudus. Itu sebabnya penulis menyimpulkan bahwa dalam konteks kitab Wahyu, Ibadah bersifat Trinitarian. Yang penulis maksudkan adalah dalam ibadah, jemaat menyembah Allah Bapa, Allah Anak dan Allah Roh Kudus. Dengan kata lain, dalam ibadah, jemaat masuk dalam relasi dengan Allah (Bapa) melalui Allah (Anak) dan oleh Allah (Roh Kudus).

\section{Theocentric}

Sebagaimana telah dipaparkan pada bagian theologia kitab Wahyu, Allah yang duduk di takhta menjadi pusat ibadah, maka sifat ibadah dalam konteks Wahyu bersifat Theocentric. Wahyu 4:1-11 adalah penglihatan 
Yohanes yang kedua. Penglihatan yang kedua ini terfokus pada Takhta (ay 2-3). Muncul 3 kali dalam ayat 2 dan 3, dan muncul 13 kali dalam seluruh pasal ini. Takhta merupakan simbol; "Otoritas Tertinggi, Kekuasaan yang Maha Agung, Kedaulatan yang mutlak.” Jadi, kedaulatan Allah merupakan sentral dalam penglihatan Yohanes. Sentralitas dari penglihatan ini, bukanlah mengenai Sorga, melainkan mengenai pusat dari Sorga ialah Takhta, mengenai Kedaulatan Allah. Tahkta atau Kedaulatan Allah, hanya mungkin dimengerti oleh orang percaya yang dikuasai oleh Roh Kudus. Karena hanya kepada orang yang diundang oleh Tuhan Yesus sendirilah, yang dikuasai oleh Roh Kudus untuk mengerti mengenai Allah yang berdaulat. ${ }^{36}$ Jadi, pusat ibadah kitab Wahyu adalah Allah, yaitu Allah yang sedang bekerja dan memerintah dunia ini, mengontrol semua kejadian dalam dunia, sehingga tidak satu peristiwa yang luput dari kedaulatan-Nya.

Sentralitas Takhta yang dilihat Yohanes, terletak pada Dia Yang Duduk Di Atas Takhta, yaitu Dia yang berdaulat. Siapakah Dia yang duduk di atas Takhta itu? Yohanes tidak bisa mengidentifikasikan dengan jelas. Karena itu, Yohanes hanya mampu melukiskan "Dia yang duduk di Takhta itu" dengan menggunakan istilah bagaikan. Bahasa manusia tidak mampu menampung bahasa Sorga. Penglihatan manusia tidak mampu membahasakan apa yang dilihatnya tentang Allah. ${ }^{37}$

\section{$\underline{\text { Redeemptif }}$}

Sifat ini menunjuk pada karya penebusan Kristus. Istilah Anak Domba dalam kitab Wahyu menunjuk kepada Yesus. Hal ini dapat ditemukan dalam kitab Wahyu bahwa Ia hampir selalu diperkenalkan dengan nama pribadi Yesus $(1: 9 ; 12: 17)$ daripada Kristus $(11: 15) .{ }^{38}$ Nama Yesus menunjuk kepada karya keselamatan yang dikerjakan-Nya. Dalam pasal 5, penyembahan ke-24 tua-tua diarahkan kepada Anak Domba karena karya penebusan-Nya. ${ }^{39}$

Kristus menerima penyataan Allah, yang kemudian Ia lanjutkan kepada Yohanes (1:1); Ia adalah Anak Domba yang disembelih dan dengan darah-Nya ia telah menebus orang kudus bagi Allah $(5: 6,9)$; dan sebagai Anak Domba, Ia akan menyambut mempelainya, itulah Gereja, ke dalam

\footnotetext{
${ }^{36}$ Lumintang, Theologia Ibadah..., 30.

${ }^{37}$ Ibid.

${ }^{38}$ George Barker Stevens, The Theology of the New Testament, (New York: Charles Scribner's Sons, 1936), 536.

${ }^{39}$ Mounce, The Book Of Revelation..., 147.
} 
pesta perkawinan $(19: 7-9 ; 21: 9)$. Yohanes mengajarkan bahwa Kristus adalah agen Allah dalam penciptaan, penebusan dan penyempurna. ${ }^{40}$

Dengan demikian, karakteristik ibadah dalam kitab Wahyu ialah Redemptif, sebagaimana ditunjukan dalam penyembahan kepada Anak Domba Allah dan Dia yang duduk di Takhta. Sifat redemptif ini berimplikasi kepada penyembah, yaitu seorang yang datang menyembah adalah seorang yang sudah mengalami karya penebusan Kristus.

\section{Theistik}

Teologi ibadah Kristen, tentu bukanlah teologi yang deistik, yaitu teologi yang menekankan pada penyembahan kepada Allah yang bersifat transenden, yang jauh di "sana" (Allah yang ada di Sorga), juga bukanlah teologi penyembahan yang pantheistik, yaitu teologi yang semata-mata menekankan pada ibadah yang imanen (Allah itu ada di mana-mana, di mana-mana ada Allah), melainkan teologi yang theistik, yaitu teologi yang mengemukakan mengenai penyembahan kepada Allah yang transenden sekaligus imanen. ${ }^{41}$

Pelukisan tentang Allah dalam penglihatan Yohanes menunjukkan betapa mulia dan tak terjangkaunya manusia berdosa untuk menghampiri Takhta yang suci itu. Kemuliaan Allah yang tak terhampiri itu menunjuk kepada sifat transcendent. Yohanes begitu takut, bahkan seperti orang mati (1:17), hal ini menunjukkan bahwa Yohanes sedang berhadapan dengan Allah yang transcendent. Tetapi ayat 17 juga menyatakan bahwa "tetapi Ia meletakkan tangan kanan-Nya di atasku." Hal ini menunjukkan bahwa Yohanes sedang berhadapan dengan Allah yang imanent. Maka memahami sifat ibadah yang theistik ini membuat penyembah dengan rasa hormat dan gentar datang beribadah kepada Allah, tetapi di sisi lain ibadah Kristen adalah ibadah dengan rasa nyaman, dan dekat dengan Allah yang imanen.

\section{Covenental}

Wahyu kepada Yohanes adalah satu dokumen perjanjian. Janice E. Leonard dalam Covenant Worship in The New Testament menuliskan bahwa: The proliferation of sevens is a clue to the book's covenant content,

\footnotetext{
${ }^{40}$ Simon J. Kistemaker, Revelation; New Teatament Commentary (Grand Rapids, Michigan: Baker Book House, 2001), 58.

${ }^{41}$ Lumintang, Theologia Ibadah..., 31.
} 
a reminder of the taking of a covenant oath, which in Hebrew is literally "to seven oneself. ${ }^{42}$ Kitab Wahyu adalah juga merupakan sebuah lukisan tentang ibadah perjanjian sebagai respons manusia baru kepada Allah yang telah membebaskan mereka.

Yohanes juga memberikan satu pola Gereja mengikuti deskripsi 24 tua-tua yang tersungkur di hadapan Anak Domba. "Lalu aku mendengar seperti suara himpunan besar orang banyak, seperti desau air bah dan seperti deru guruh yang hebat, katanya: Haleluya! Karena Tuhan, Allah kita, Yang Mahakuasa, telah menjadi raja. Marilah kita bersukacita dan bersorak-sorai, dan memuliakan Dia! Karena hari perkawinan Anak Domba telah tiba, dan pengantin-Nya telah siap sedia" $(19: 6,7)$. Di dalam ibadah Gereja, "Kota suci, Yerusalem baru," perjanjian itu mendapat penggenapannya: Lalu aku mendengar suara yang nyaring dari takhta itu berkata: Lihatlah, kemah Allah ada di tengah-tengah manusia dan Ia akan diam bersama-sama dengan mereka. Mereka akan menjadi umat-Nya dan Ia akan menjadi Allah mereka" (21:3).

Dengan demikian, sifat ibadah covenental menuntut penyembah untuk mengalami rekonsiliasi yang adalah merupakan pintu masuk kepada ibadah. Karena perjanjian Allah digenapi di dalam diri Tuhan Yesus, maka penyembah terlebih dahulu harus mengalami rekonsiliasi. Rekonsiliasi ini terjadi di kayu salib. Itu berarti, dengan menerima Kristus sebagai Tuhan dan Juruselamat, seseorang memperoleh pintu masuk ke dalam ibadah.

\section{Transformatif}

Sifat ibadah yang transformatif ini dapat dicermati dalam kitab Wahyu, khususnya pada saat berhadapan dengan Takhta Allah. "Ketika aku melihat Dia, tersungkurlah aku di depan kaki-Nya sama seperti orang yang mati; tetapi Ia meletakkan tangan kanan-Nya di atasku, lalu berkata: 'Jangan takut! Aku adalah Yang Awal dan Yang Akhir (1:17)." Maka tersungkurlah ke-24 tua-tua itu di hadapan Dia yang duduk di atas takhta itu, dan mereka menyembah Dia yang hidup sampai selama-lamanya. Dan mereka melemparkan mahkotanya di hadapan takhta itu, sambil berkata: "Ya Tuhan dan Allah kami, Engkau layak menerima puji-pujian dan hormat dan kuasa; sebab Engkau telah menciptakan segala sesuatu; dan oleh karena kehendak-Mu semuanya itu ada dan diciptakan" (4:10).

42 Janice E. Leonard, Covenant Worship In The New Testament, in The Biblical Foundations of Christian Worship, edit by Robert E. Webber (Peabody, Massachusetts: Hendrickson, 1993), 63. 
Transformasi terjadi ketika Yohanes berhadapan atau melihat Yesus dalam kemuliaan-Nya. Menyadari ketidaklayakan di hadapan Dia yang layak menerima segala hormat dan pujian, serta kemuliaan, ${ }^{43}$ adalah transformasi pikiran.

Transformasi berikut adalah sikap 24 tua-tua yang tersungkur di hadapan Dia yang duduk di atas Takhta, serta tindakan melemparkan mahkota, juga menyatakan ketidaklayakan, di hadapan Dia yang layak menerima penyembahan umatnya. Kistemaker menuliskan tentang sikap 24 tua-tua demikian: they had recieved these crowns from God for being overcomes, but they respectfully return them to God to assign to him all glory and honor. ${ }^{44}$

Dengan demikian, orang yang beribadah harus menunjukkan transformasi baik pikiran, maupun sikap hidup. Transformasi ini tentu karena karya Roh Kudus yang mengaplikasikan karya penebusan Kristus bagi kita.

\section{KONTRIBUSI BAGI IBADAH MASA KINI}

Kontribusi kepada Gereja-gereja masa kini. Ibadah Kristen yang memadai perlu memperhatikan beberapa prinsip ibadah di bawah ini.

Pertama, ibadah Kristen harus Biblikal. Bersumber dari firman Tuhan dan bukan pengalaman atau perasaan atau emosi belaka.

Kedua, ibadah Kristen harus bersifat dialog. Dalam ibadah, Allah berbicara dan mendengar. Dengan kuasa Roh Kudus, Allah menantang kita, menghibur kita, dan membangunkan kita. Dan oleh Roh Kudus, kita mendengar dan memberi respons dengan pujian, pengakuan, kesaksian dan dedikasi.

Ketiga, ibadah Kristen bersifat covenental. Dalam ibadah, kebaikan Allah dan perjanjian yang baru dengan kita di dalam Kristus dibaharui, diteguhkan dan dimateraikan. Hubungan kita dengan Allah bukan didasarkan pada kontrak, tetapi pada perjanjian.

Keempat, ibadah Kristen harus Trinitarian. Dalam ibadah kita arahkan segala hormat, pujian dan kemuliaan hanya kepada Allah Trinitas, Bapa, Anak dan Roh Kudus. Allah adalah yang dengan anugerah-Nya mengundang kita beribadah dan kemudian Ia mendengar bahkan melihat respons kita.

\footnotetext{
${ }^{43}$ Kistemaker, Revelation: New Testament..., 99.

${ }^{44}$ Ibid., 193.
} 
Kelima, ibadah Kristen harus communal. Injil Yesus Kristus menarik kita masuk dalam kehidupan bersama dengan orang lain.

\section{PENUTUP: KESIMPULAN}

Ibadah dalam Perjanjian Baru adalah penggenapan perjanjian Allah kepada manusia, bahwa akhirnya semua orang akan berhadapan dengan takhta Allah yang kudus, dan Anak Domba. Semua bangsa akan bertekuk lutut di hadapan Anak Domba yang menghapus dosa isi dunia. Dengan kata lain, Allah Tritunggal adalah arah dan alamat pujian dan penyembahan orang percaya. Allah Bapa disembah di dalam nama Allah Anak yaitu Yesus Kristus dan dikerjakan oleh Allah Roh Kudus sebagai dinamisator ibadah. Ibadah kitab Wahyu adalah ibadah kepada Tuhan, Allah Bapa, Pencipta alam semesta (Why 4:10-11). Yesus Kristus, Anak Allah, Penebus dan Anak Domba Allah (Why 1:5,6; 5:11-14; 7:9-10). Roh Kudus, ialah tujuh Roh yang ada di hadapan takhta-Nya (Why.1:4). Ibadah dalam kitab Wahyu adalah Trinitarian. Bukan kepada; Iblis, "seluruh dunia menyembah naga itu" (13:3); anti Kristus, "iblis memberi kekuasaan kepada binatang itu dan mereka menyembah dia" (13:4); kepada nabi anti-Kristus, "ia menyebabkan seluruh bumi menyembah binatang pertama" (13:11-12). Allah Tritunggal adalah pusat ibadah Perjanjian Baru sebagaimana dinyatakan dalam kitab Wahyu. 